\title{
Transcatheter mitral regurgitation treatment: Let's learn from surgeons
}

\author{
Leonid Sternik, MD
}

\author{
From the Department of Cardiac Surgery, Sheba Medical Center, Tel-Hashomer, Israel. \\ Disclosures: Author has nothing to disclose with regard to commercial support. \\ Received for publication May 1, 2016; accepted for publication May 2, 2016; available ahead of print May 25, \\ 2016 \\ Address for reprints: Leonid Sternik, MD, Department of Cardiac Surgery, Sheba Medical Center, Tel-Hashomer, \\ Israel 52621 (E-mail: leosternik@hotmail.com). \\ J Thorac Cardiovasc Surg 2016;152:328-9 \\ $0022-5223 / \$ 36.00$ \\ Copyright $(c) 2016$ by The American Association for Thoracic Surgery \\ http://dx.doi.org/10.1016/j.jtcvs.2016.05.010
}

Undoubtedly, we are entering an era of transcatheter treatment of heart valves. In this issue of the Journal, Testa and colleagues ${ }^{1}$ have done a great job providing a very detailed and extensive review of almost all techniques and devices. I believe that their classification of techniques of transcatheter mitral procedures is very useful. Navigation of the mitral valve is more difficult than navigation of the aortic valve. To remain true to transcatheter mode, we must proceed transseptally and navigate some difficult angles. Obviously, effective percutaneous methods are better than transapical or transatrial approaches, because the latter approaches are still surgery, with all the attendant risks and operative trauma, especially for elderly and ill patients.

Mitral valve anatomy can be more challenging than coronary or aortic valve anatomy from an interventional point of view. I believe that inventors and invasive cardiologists could learn from more than 40 years of extensive experience gained by surgeons with mitral valve procedures. We know that almost any type of mitral repair requires a ring. In some cases, a ring may be the only good option for repair. $^{2}$ Techniques providing mitral valve annuloplasty thus could have some advantages with respect to techniques dealing only with leaflets or chordae. De Bonis and colleagues ${ }^{3}$ have suggested that it would be interesting to combine the MitraClip (Abbott Vascular, Santa Clara, Calif) with mitral annuloplasty, as in surgery. In most surgical cases, the edge-to-edge stich needs the addition of annuloplasty. Annuloplasty can improve and provide durability to transcatheter artificial chordae repair. I would imagine that annuloplasty similar to surgical or direct annuloplasty, according to the classification of this article, may be the best. Indirect annuloplasty still requires additional data. Surgery can help us understand how an annuloplasty ring or band should be placed. Surgeons usually anchor annuloplasty bands to fibrous trigones; this prevents further dilation of the mitral annulus. An annuloplasty system involving only a coronary sinus, for

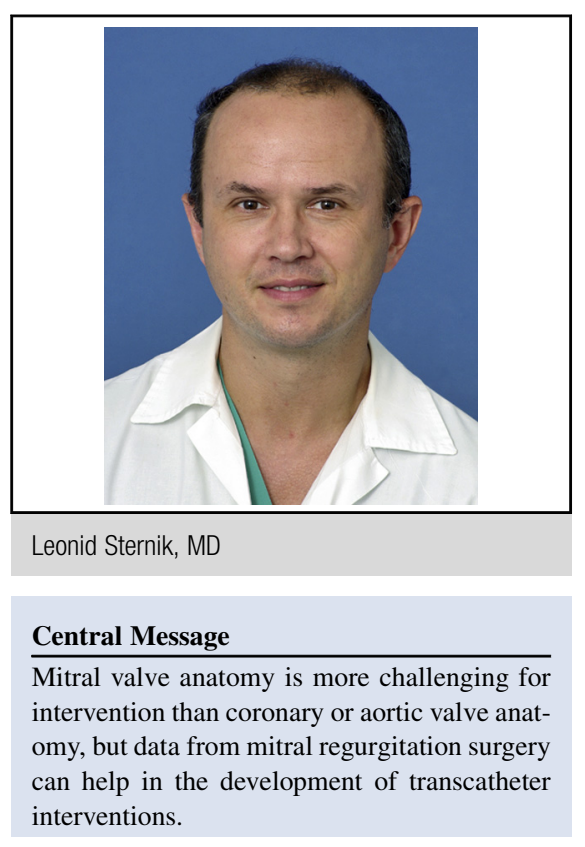

See Articles page 319 and 330 .

See Editorial Commentary page 336.

example, thus cannot be as good as a technique anchoring a band or ring to fibrous trigones and attached to the posterior or whole annulus. Naturally, an annuloplasty band or ring should be securely attached to the tissue of the mitral annulus to prevent dehiscence. In addition, one must be careful not to damage a circumflex artery.

Recent data suggest that mitral valve replacement may have advantages, in some cases, relative to repair. ${ }^{4}$ We need a reliable transcatheter mitral valve implantation system. The situation differs from aortic valve implantation. Testa and colleagues ${ }^{1}$ correctly claim that fixation of the mitral prosthesis is challenging, because of the lack of heavy annular calcification. In addition, fixation relying on radial force poses the risk of compression of adjacent structures, such as the circumflex artery, conduction system, left ventricular outflow tract, and so on. Excessive radial forces can cause a devastating complication of posterior rupture. Probably, grasping leaflets with force applied from the atrial to ventricular side of the leaflet can be better and safer for prosthesis fixation. 
I conclude that surgical experience can enhance transcatheter mitral therapy, probably more than other transcatheter procedures.

\section{References}

1. Testa L, Latib A, Montone RA, Bedogni F. Transcatheter mitral valve regurgitation treatment: state of the art and a glimpse to the future. J Thorac Cardiovasc Surg. 2016;152:319-27.
2. Ben Zekry S, Spiegelstein D, Sternik L, Lev I, Kogan A, Kuperstein R, et al. Simple repair approach for mitral regurgitation in Barlow disease. J Thorac Cardiovasc Surg. 2015;150:1071-7.e1.

3. De Bonis M, Lapenna E, Pozzoli A, Giacomini A, Alfieri O. Edge-to-edge surgical mitral valve repair in the era of MitraClip: what if the annuloplasty ring is missed? Curr Opin Cardiol. January 8, 2015 [Epub ahead of print].

4. Goldstein D, Moskowitz AJ, Gelijns AC, Ailawadi G, Parides MK, Perrault LP, et al; CTSN. Two-year outcomes of surgical treatment of severe ischemic mitral regurgitation. N Engl J Med. 2016;374:344-53. 